\title{
In Vitro Selection of Irradiated Plantlets of Vanilla Planifolia Jacks. In the Face of Water Stress
}

Lourdes GEORGINA Iglesias-Andreu ( $\sim$ liglesias@uv.mx )

Universidad Veracruzana Instituto de Biotecnologia y Ecologia Aplicada https://orcid.org/0000-0002-1364-7773

Alma Laura Ramos-Castellá

Universidad Veracruzana Instituto de Biotecnología y Ecología Aplicada: Universidad Veracruzana Instituto de

Biotecnologia y Ecologia Aplicada

María de Lourdes Palafox Chávez

Instituto Estatal de Oncología "Dr. Miguel Dorantes Mesa"

\section{Research Article}

Keywords: Gamma irradiation, mutagenesis, osmoregulators, polyethylene glycol, tissue culture

Posted Date: February 9th, 2021

DOI: https://doi.org/10.21203/rs.3.rs-172096/v1

License: (c) This work is licensed under a Creative Commons Attribution 4.0 International License. Read Full License 


\section{Abstract}

Currently, premature fruit fall is one of the major problems of vanilla (Vanilla planifolia Jacks.) cultivation. This phenomenon has been related to its high susceptibility to drought, a consequence of the low genetic variability of this crop. For this reason, it is of great importance to undertake genetic improvement programs in order to obtain genotypes with greater tolerance to this abiotic factor. With this aim, the present work was developed, in order to select in vitro irradiated shoots, with different doses of gamma rays (0.5 to $19 \mathrm{~Gy}$ ), cultivated in Murashige \& Skoog (MS) medium containing: 0,10 and $15 \%$ of polyethylene glycol (PEG). The results showed a greater proliferation of irradiated shoots, with doses of 0.5 and $1 \mathrm{~Gy}(8.88 \pm 3.04$ and $6.43 \pm 0.98)$. Shoots irradiated with $0.5 \mathrm{~Gy}$ had a faster growth $(19.26 \pm 6.87$ $\mathrm{mm}$ ) while those irradiated with $3 \mathrm{~Gy}$ showed a higher number of leaves $(2.38 \pm 0.71)$. Nodal segments of shoots irradiated with 9, 15, 17 and $19 \mathrm{~Gy}$, lost their ability to multiply. Vitroplants from $13 \mathrm{~Gy}$, grown in a medium containing 15 $\%$, showed greater tolerance to water deficit. These vitroplants kept their leaves and showed significant differences in the accumulation of betaine glycine $(21.46 \pm 4.55 \mu \mathrm{mol}$ betaine glycine/dry weight), in relation to the accumulation of nonirradiated vitroplants. Therefore, it is considered that the dose of $13 \mathrm{~Gy}$ can generate variability and improve tolerance to simulated water stress in vitro.

\section{Introduction}

Of all the abiotic stresses that affect plants, drought is considered one of the most damaging, due to the serious productive effects it causes. Epiphytic plants, such as the Vanilla planifolia Jacks., are often subject to extremely high evaporation rates, creating conditions of extreme aridity. For this reason, they have adaptations that allow them to quickly capture water and store it in their tissues (succulence), in addition they have developed a photosynthetic route known as "Crassulacean Acid Metabolism" (CAM) (Díez et al. 2017). This route allows vanilla to reduce losses due to transpiration, at the time of the nocturnal absorption of $\mathrm{CO}_{2}$. (Díez et al. 2017; Gantiva et al. 2020). However, drought and high irradiation can negatively affect the metabolism of this important crop (Díez et al. 2017; Gantiva et al. 2020). Vanilla plants, after a short period of drought (48 days), significantly decrease the nocturnal assimilation of $\mathrm{CO}_{2}$, and the formation of organic acids; in addition, they lose chlorophyll, which affects all stages of CAM photosynthesis (Gantiva et al. 2020).

It has been identified the existence of a period of hydric deficit in the "Totonacapan region", considered the area of highest vanilla production in Mexico. This period extends during most of the year, affecting particularly the time of flowering of vanilla (April-June) (Villarreal and Herrera 2018). The most widespread systems of vanillin production are the traditional systems ("acahual" shade) and the orange tree as a support, in both cases seasonal irrigation predominates (Barrera et al. 2009). It is estimated, that only $8 \%$ of vanilla producers have some type of irrigation system (Sánchez et al. 2001). Drought, along with high temperatures and irradiation, has been associated with premature fruit drop (Hernández et al. 2019) causing losses of up to $90 \%$ in Mexico's production (Hernández et al. 2019). Therefore, it is of great interest to obtain promising genotypes of $V$. planifolia, which present a greater tolerance to this abiotic factor.

Mutations induction provides a viable option for the generation of a new source of resistance to biotic/abiotic stresses (Suprasanna and Mirajkar 2015). lonizing radiation, especially gamma radiation, is considered the most widely used physical mutagen for breeding new varieties (Maluszynski et al. 2000). It has been demonstrated that the use of low doses of gamma radiation could generate an adaptive "hormetic" response on the growth and development of plants, as well as an increased production of enzymes responsible for the elimination of "Reactive Oxygen Species" (ROS) (Jan et al. 2012).There are several ways to evaluate the increase of drought tolerance in an early way, among them, the measurement of morphological characters and the accumulation of compatible solutes, such as: glycine betaine (GB), mannitol, sorbitol, polyols, polyamines and proline. Their accumulation is favored in situations of water deficit or saline stress, since they provide stress tolerance to the cell, without interfering with the cellular machinery (Giri 2011). GB and proline have positive 
effects on enzyme functioning, membrane integrity and osmotic adjustment, in plants under abiotic stress conditions (Ashraf and Foolad 2007).

In vitro selection using osmotic agents such as Polyethylene glycol 6000 ( $\mathrm{PEG}_{6000}$ ), is a feasible way to obtain greater drought tolerance in this crop. Therefore, this work was carried out with the aim of obtaining genetic materials of $V$. planifolia, with higher tolerance to hydric deficit, through the combined use of ionizing radiation techniques and in vitro selection.

\section{Materials And Methods}

\section{In vitro mutagenesis induction}

Shoots of V. planifolia from "Papantla" Veracruz, Mexico, provide by the germplasm bank from the Institute of Biotechnology and Applied Ecology of the Veracruz University, were established and multiplied, following the procedure reported by Ramos et al. (2014). Once the shoots were formed, they were multiplied using nodal segments. The explants with 3 to 4 shoots / conglomerate, approximately $1.2 \mathrm{~cm}$ in diameter, were cut, at an approximate height of $1.5 \mathrm{~cm}$. Subsequently, these explants were cultivated in vitro, in the multiplication medium indicated by Ramos et al. (2014). After 10 days, these were irradiated with different doses $(0,0.5,1,3,5,7,9,11,13,15,17$ and $19 \mathrm{~Gy})$ of gamma rays. The irradiation was performed at the "Dr. Miguel Dorantes Mesa” Cancerology Center (CECAN) in the city of Xalapa, Veracruz, using a source (Theraton 780E). Twelve explants (conglomerate of shoots) by treatment were irradiated, for which a field of $12 \times 12 \mathrm{~cm}^{2}$ was prepared using the $\mathrm{SSD}_{80}$ (Source-skin distance $80 \mathrm{~cm}$ ) technique. The irradiations were carried out at $3 \mathrm{~cm}$ depth, so that the maximum dose reached the apexes of all the shoots.

\section{In vitro selection for water deficit}

Shoots obtained from irradiated explants were multiplicated in MS medium supplemented with $9.55 \mu \mathrm{M}$ benzyladenine (BA) and $100 \mathrm{ML} \mathrm{L}^{-1}$ coconut water and $3 \%$ of sucrose (Ramos et al. 2014). A total of 60 plants rooted from each doses of irradiation ( $0,3,7$ and $13 \mathrm{~Gy}$ ) were obtained. Apexes of $2 \mathrm{~cm}$ long approximately were cut and cultivated in $50 \mathrm{~mL}$ tubes containing $20 \mathrm{~mL}$ of MS medium, $3 \%$ of sucrose. Three levels of $\mathrm{PEG}_{6000}(0,10$ and $15 \%)$ were used, keeping 20 apexes by treatment for 70 days.

\section{Morphological and biochemical evaluation}

20 apexes from each treatment To know the effect of radiation on the morphological characteristics of the shoots, the following variables were evaluated: percentage of survival as well as the number of shoots, length and diameter of the stem and number of leaves) in 20 shoots per treatment two months after irradiation. The variables were analyzed by a Kruskal-Wallis analysis, followed by a Mann-Whitney test $(p<.05)$ with the STATISTICA, v.8.0.

To evaluate the morphological response in face of PEG, a total of 120 vitroplants (10 for each $\mathrm{PEG}_{6000}$ treatment) were evaluated. The data of the variables: stem diameter, leaf length, leaf width, leaf thickness, longest root length and fresh weight were processed by ANOVAs followed by Tukey's test $(p<.05)$. Similarly, the data of the variables: stem length, number of leaves and number of roots were analyzed by the Kruskal-Wallis test, followed by a Mann-Whitney test $(p<.05)$, with the STATISTICA, v 8.0.

Secondary osmolytes were quantified: proline and GB, accumulated in vitro and subjected to different PEG treatments. Proline concentration was determined following the protocol of Bates et al. (1973), while WB concentration was evaluated according to the protocol of Grieve and Grattan (1983). The leaf tissue of the vitroplants subjected to each PEG treatment was cut and weighed and then divided into 3 replicates to form 3 pools, from which proline and GB were quantified. The 
results obtained were analyzed by the Kruskal-Wallis test followed by the Mann-Whitney test $(p<0.05)$ with the STATISTICA, v.8.0

\section{Results}

\section{In vitro mutagenesis induction}

Significant differences were detected among treatments, for all the morphological characters evaluated in the shoots, except for the diameter of the stem. The highest values for number and length of shoots were obtained with the dose of 0.5-Gy, while with the 1-Gy dose there was a slight increase in the number of shoots, although these were significantly smaller, than those from the control treatment. A higher number of leaves was observed in the shoots irradiated with 3-Gy (Table 1).

On the other hand, the dose of 9-Gy, had a negative effect, both in the number of shoots, as in its length and number of leaves. Shoots subjected to 11-Gy also had significantly smaller leaves than those of the control, while shoots irradiated with 13-Gy showed no significant difference with the control. The 15-Gy dose produced fewer shoots, which made them larger than those of the control. Although no significant differences were observed in the number of shoots, derived from the 19-Gy dose, it was found that they were significantly smaller and had fewer leaves, and therefore their development was slower (Fig. 1).

It was interesting to note, that most of the doses used, did not affect the survival of the irradiated shoots. However, survival of shots subjected to 5 -Gy was $50 \%$, unlike those subjected to $7-$ Gy and $19-$-Gy which only had a mortality of $25 \%$; therefore, the median lethal dose (50\%LD) could not be adequately defined in this study. On the other hand, the shoots submitted to the doses of 9,15,17 and 19Gy, lost their capacity of multiplication, for what, it was not possible to achieve the generation of new shoots, from their nodal segments.

\section{In vitroselection for water deficit}

\section{Morphological response of vitroplants submited to PEG}

The irradiated shoots were rooted and cultured in vitro, in 10 and 15\% PEG. In all of them, it was observed a decrease in the morphological variables evaluated, in comparison with what was observed in the treatment without PEG. As the PEG concentration increased, the differences with the control treatment (without PEG), were more evident. A better morphological response to drought, caused by PEG (Table 2), was observed in vitroplants generated from irradiated shoots.

It was found, that vitroplants from irradiated 3 and 13-Gy shoots, grown on non-PEG media, had the highest fresh weight values, compared to those from non-irradiated or 7-Gy irradiated shoots. Vitroplants derived from irradiated 3-Gy shoots, were characterized by increased stem diameter thickness, however, no difference was observed with those derived from non-irradiated and 7-Gy irradiated shoots. However, no differences were observed among those from non-irradiated and 7Gy irradiated shoots. In the same way, the vitroplants of shoots submitted to 13-Gy, showed longer roots than those of the control treatment.

The vitroplants from shoots irradiated at 3-Gy and grown at 10\% PEG, showed a larger stem diameter, compared to those from 7 and 13-Gy, but without differences with those from the control treatment. These also had the highest fresh weight, compared to those derived from 7-Gy, but without differences with those from the control and 13-Gy treatments. The vitroplants from 13-Gy had the highest number of leaves, differing significantly from those from the control and 3-Gy treatments. The root length of the vitroplants derived from 13-Gy was significantly greater than those derived from 7-Gy, but without differences from those derived from the non-irradiated and 3-Gy treatments. 
It was interesting to observe, the existence of significant differences in 7 of the 9 morphological variables evaluated, in the cultivated vitroplants in $15 \%$ of PEG. The vitroplants, from three radiation treatments evaluated, were characterized by having longer leaves, than those derived from the control treatment. The 3-Gy vitroplants showed a fresh weight and a stem diameter significantly larger, than those of the control, while those coming from 13 and 3-Gy showed wider leaves and longer roots, compared to the control treatment. The 13-Gy vitroplants had a greater number of leaves, which were thicker, than those observed in the control treatment (Table 2).

\section{Biochemical response of vitroplants submited to PEG}

No correlation was observed between proline concentration and the concentration of PEG added to the culture medium (Figs. 2a, 2b and 2c). However, significant differences were detected among vitroplants with different radiation doses. In $0 \%$ of PEG 13-Gy vitroplants had a lower proline concentration $(0.45 \pm 0.19)(H(3, N=8)=4,631, p=0.0022)$. Not significant differences were found in vitroplants grown at 10\% PEG $(H(3, N=8)=1.89, p=0.59)$. In $15 \%$ PEG the control treatment ( $0-\mathrm{Gy})$ had the highest concentration of proline (3.57 \pm 0.18$)$ in comparison with 7 and $13 \mathrm{~Gy}(0.99 \pm 0.21$ and $1.2 \pm 0.13$ respectively) but without significant differences with $3-G y(2.5 \pm 0.43),(H(3, N=8)=20.08479, p=0.0002$.

A correlation was found in the accumulation of GB osmolyte. GB increased with increasing PEG concentration (Fig.2). The treatment whit $0 \%$ of PEG had a low concentration of GB however 3 and $13 \mathrm{~Gy}$ showed a higher concentration of GB (0.58 \pm 0.03 , and $0.62 \pm 0.08 \mu \mathrm{mol}$ of betaine glycine / dry weight, respectively) differing of $7 \mathrm{~Gy}(0.38 \pm 0.01$ and $0.39 \pm 0.05$ $\mu \mathrm{mol}$ of betaine glycine / dry weight $)(H(3, N=8)=23.37, p=0.000)$.

The control vitroplants (0-Gy) growed in 10\% PEG, had a GB concentration of $4.06 \pm 1.78 \mu$ mol betaine glycine / dry weight, which differed from the content shown by the 7 and 13-Gy vitroplants $(2,67 \pm 0.21$ and $2.52 \pm 1.28$ mol betaine glycine / dry weight respectively); no difference was detected, however, with those of 3-Gy (3.09 $\pm 0.46 \mu$ mol betaine glycine / dry weight), $(H(3, N=8)=9.96, p=0.012)$.

The treatment with $15 \%$ of PEG showed that 13-Gy vitroplants had the highest concentrations of GB $(21.46 \pm 4.55 \mu \mathrm{mol}$ glycine betaine / dry weight), differing significantly from other treatments $(H(3, N=8)=23.21, p=0.000)$. 3-Gy vitroplants accumulate $12.32 \pm 3.65 \mu \mathrm{mol}$ glycine betaine / dry weight; 0 -Gy vitroplants showed a GB content of $9.21 \pm 2.27 \mu \mathrm{mol}$ of glycine betaine / dry weight, and 7Gy vitroplants had the lowest amount of GB (5.93 $\pm 0.20 \mu \mathrm{mol}$ of glycine betaine / dry weight) These results show, that $13-$ Gy vitroplants produced a $133 \%$ increase in GB concentration, in relation to what was detected in the control vitroplants (Fig 2).

\section{Discussion}

The results obtained in this study are consistent with several studies indicating that low-dose irradiation can have a stimulating effect on growth and shoot production (Jan et al. 2012). It is likely that the use of lower doses of gamma rays ( 0.5 to $7-G y)$ will be well suited to generate a "hormetic effect" although, the knowledge regarding the mechanisms, underlying the enhanced abiotic tolerance, is far from fully understood. In the case of Gypsophila paniculata L. (baby breath), a stimulating effect was observed in the number of shoots, produced when irradiating explants with doses of 0.75 and 1-Gy, while shoots irradiated with doses of 1-Gy produced higher shoots (Barakt and El-Samak 2011). Similarly, Kim et al. (2005) observed a "gamma ray-hormetic effect" on the growth of Capsicum annuum L. shoots irradiated with 2 and 4 Gy, while doses of 8 and 16-Gy, exerted an inhibitory effect.

In V. planifolia, Lestari et al. (2006) irradiated somatic embryos in globular phase (1 and 3-Gy) and torpedo (0.3-Gy), as well as seeds, with different doses (10,20 and $30 \mathrm{~Gy}$ ) of gamma rays, in order to submit them to in vitro selection with Fusarium oxysporum filtrates, as a way to obtain genetic materials with higher tolerance to this fungal pathogen. However, when it is required, as in this case, to extend the genetic variation of the crop, higher doses of gamma radiation need to be used. That is why the results obtained in this study show, that the most appropriate gamma radiation dose to use in this 
crop is 13-Gy. Therefore, the use of this dose is recommended to broaden the genetic base of the crop, without compromising its regenerative potential.

In vitro selection with PEG, has been very useful for selecting mutants, with higher drought tolerance in various crops such as: Glycine max L. Merrill (Saepudin et al. 2017), Musa L. (Moreno et al. 2017), Saccharum officinarum L. (Abbas et al. 2014), Prunus L. (Sorkheh et al., 2011) Oryza sativa L. (Shabir et al. 2010), and Solanum tuberosum L. (Gopal and Iwama 2007). In the above-mentioned studies, morphological differences associated with drought tolerance have been detected. The vitroplants coming from the doses of 13 and 3-Gy were the ones that presented a greater number of leaves, leaves with more length, width and thickness than the ones observed in the rest of the evaluated treatments, which is important considering that Vanilla has succulent leaves as hydric reservoir, which is directly affected by drought.

The biochemical results obtained in this work coincide with those obtained by Chandran and Phutur (2009), who, when quantifying the proline content, in vanilla plants cultivated in field under water deficit, found that proline accumulation does not represent a defense mechanism, against drought in this species. Similarly, increases in GB content as PEG concentration increased, suggest that this osmolyte seems to accumulate as an adaptive physiological strategy of Vanilla to drought. GB is an amphoteric quaternary amine, which plays an important role, as a compatible solute in many plants subjected to various types of abiotic stress such as salinity, temperature, oxidative stress and drought (Sakamoto and Murata, 2002; Chen and Murata 2011). It has been found in different species (Sorghum bicolor L.) Moench, Yang et al. 2003; Oryza sativa L., Shabir et al. 2010; Saccharum officinarum L., Abbas et al. 2014), that genotypes tolerant to drought stress tend to accumulate more GB than susceptible. Future studies will allow evaluating the usefulness of the results obtained, in the programs of genetic improvement to drought, which are currently developed in this crop.

This study shows that the application of low-dose gamma radiation to $\mathrm{V}$. planifolia shoots can promote the generation of genetic materials with improved drought tolerance. The lower irradiation doses evaluated in this study appeared to have a hormetic effect, while the higher doses had an inhibitory effect on the generation of the nodal segment of the shoot. It was proved that the dose of $13 \mathrm{~Gy}$ allowed obtaining plants with good capacity of multiplication, with a better morphological and biochemical response to drought. The greater accumulation of osmolytes as GB in the irradiated materials constitutes the base to achieve important advances in the biotechnological genetic improvement developed in this cultivation for the generation of promising lines with greater tolerance to abiotic stress.

\section{Abbreviations}

CAM: Crassulacean acid metabolism

$\mathrm{SSD}_{80}:$ Source-skin distance $80 \mathrm{~cm}$

GB: Glycine betaine

$\mathrm{PEG}_{6000}$ : Polyethylene glycol 6000

ROS: Reactive oxygen species

\section{Declarations}

Funding. This word was funding by the Program for the Improvement of Teachers (PROMEP) through the project "Biotechnological Bases for the genetic improvement of Vanilla planifolia" of the Conservation, Management and Improvement network.

Conflicts of interest/Competing interests. The authors declare that they have no conflicts of interest. 
Availability of data and material (data transparency). The datasets generated during and/or analysed during the current study are available from the corresponding author on reasonable request.

Code availability. Not applicable

Authors' contributions. All authors contributed to the study conception and design. Conceptualization: [Lourdes Georgina Iglesias Andreu and Alma Laura Ramos Castellá]; Methodology: [Lourdes Georgina Iglesias Andreu, Alma Laura Ramos Castellá and Lourdes Palafox Chávez], Formal analysis and investigation: [Lourdes Georgina Iglesias Andreu and Alma Laura Ramos Castellá]; Writing - original draft preparation: [Alma Laura Ramos Castellá]; Writing - review and editing: [Lourdes Georgina Iglesias Andreu, Alma Laura Ramos Castellá and Lourdes Palafox Chávez]; Funding acquisition: [Lourdes Georgina Iglesias Andreu]. All authors read and approved the final manuscript.

Ethics approval. Not applicable

Consent to participate. All authors agree own participation in this study

Consent for publication. The authors consent publication of this study

\section{References}

1. Abbas SR, Ahmad SD, Sabir SM, Shah AH (2014) Detection of drought tolerant sugarcane genotypes (Saccharum officinarum) using lipid peroxidation, antioxidant activity, glycine-betaine and proline contents. J. Soil Sci Plant Nut 14 (1): 233-243. http://dx.doi.org/10.4067/S0718-95162014005000019.

2. Ashraf M, Foolad MR (2007) Roles of glycine betaine and proline in improving plant abiotic stress resistance. Environ Exp Bot 59: 206-216. https://doi.org/10.1016/j.envexpbot.2005.12.006.

3. Barakat MN, El-Sammak H (2011) In vitro mutagenesis, plant regeneration and characterization of mutants via RAPD analysis in baby breath Gypsophila paniculata L. Aust J Crop Sci 5: 214-222.

https://doi.org/10.1016/j.indcrop.2014.12.005.

4. Barrera RA, Herrera CB, Jaramillo VJ, Escobedo GJ, Bustamante GA (2009) Caracterización de los sistemas de producción de vainilla (Vanilla planifolia A.) bajo naranjo y en malla sombra en el Totonacapan. Trop Subtrop Agroecosystems 10 (2): 199-212.

5. Bates LS, Waldren RP, Teare ID (1973) Rapid determination of free proline for water stress studies. Plant Soil 39: 205208. https://doi.org/10.1007/BF00018060.

6. Chandran S, Puthur J (2009) Assorted response of mutated variants of Vanilla planifolia Andr. towards drought. Acta Physiol Plant 31:1023-1029. https://doi.org/10.1007/s11738-009-0321-4.

7. Chen TH, Murata N (2011) Glycinebetaine protects plants against abiotic stress: mechanisms and biotechnological applications. Plant Cell Environ 34: 2-20. https://doi.org/10.1111/j.1365-3040.2010.02232.x.

8. Diez MC, Moreno F, Gantiva EA (2017). Effects of light intensity on the morphology and CAM photosynthesis of Vanilla planifolia Andrews. Rev Fac Nac Agron 70 (1): 8023-8033. http://dx.doi.org/10.15446/rfna.v70n1.61736.

9. Gantiva EA, Díez MC, Moreno F (2020) Efecto de la interacción luz-agua sobre la fotosíntesis de la Vanilla planifolia (Orchidaceae). Rev Biol Trop 68 (4): 1250-1261.

10. Giri J (2011) Glycinebetaine and abiotic stress tolerance in plant. Plant Signal Behav 6: 1746-1751. https://doi.org/10.4161/psb.6.11.17801.

11. Gopal J, Iwama K (2007) In vitro screening of potato against water-stress mediated through sorbitol and polyethylene glycol. Plant Cell Rep 26: 693-700. https://doi.org/10.1007/s00299-006-0275-6. 
12. Grieve CM, Grattan SR (1983) Rapid assay for determination of water soluble quaternary ammonium compounds. Plant Soil 70: 303-307. https://doi.org/10.1007/BF02374789.

13. Hernández J, Curtí S, Ríos A (2019) Retención de frutos en Vanilla planifolia Jacks ex Andrews como reguladores de crecimiento. AgronMesoam. Doi:10.15517/am.v30i3.33988

14. Jan S, Parween T, Siddiqi TO, Mahmooduzzafar (2012) Effect of gamma radiation on morphological, biochemical, and physiological aspects of plants and plant products. Environ Rev 20: 17-39. https://doi.org/10.1139/a11-021

15. Kim JH, Chung BY, Kim JS, Wi SG (2005) Effects of in plants gamma-irradiation on growth, photosynthesis, and antioxidative capacity of red pepper (Capsicum annuum L.) plants. J Plant Biol 48: 47-56.

https://doi.org/10.1007/BF03030564

16. Lestari EG, Sukmadjaja D, Mariska, Dan I (2006) Perbaikan ketahanan tanaman panili terhadap penyakit layu melalui kultur in vitro. Journal Litbang Pertanian 25(4):149-153

17. Maluszynski M, Nichterlein, Van Zanten K, Ahloowalia BS (2000) Officially released mutant varieties - the FAO/IAEA database. Mutation Breeding. FAO-IAEA, Vienna

18. Moreno BL, Reyes M, Rodríguez M, Kosky RG, Berkis R, Chong PB (2017) Respuesta de cultivares de Musa spp. al estrés hídrico in vitro inducido con polietilenglicol 6000. Rev Colomb Biotecnol 19 (2): 75-85. Doi:

10.15446/rev.colomb.biote.v19n2.60405

19. Ramos CA, Iglesias AL, Bello BJ, Lee EH (2014) Improved propagation of Vanilla (Vanilla planifolia Jacks. ex. Andrews) using a temporary immersion system. In Vitro Cell Dev-PI 50: 576-581. https://doi.org/10.1007/s11627-0149602-8

20. Saepudin A, Khumaida N, Sopandie D, Wahyuning S (2017) In vitro selection of four soybean genotypes using PEG for drought tolerance. J Agron Indones 45 (1): 14-22. https://doi.org/10.24831/jai.v45i1.13749.

21. Sakamoto A, Murata N (2002) The role of glycine betaine in the protection of plants from stress: clues from transgenic plants. Plant Cell Environ 25: 163-171. Doi: 10.1046/j.0016-8025.2001.00790.x.

22. Sánchez MS, Becerril AE, Tijerina L, Santizo JA (2001) Crecimiento y desarrollo de Vainilla en tres sistemas de producción en Papantla, Veracruz. Rev Fitotec Mex 24: 49-56.

23. Shabir H, Parvez A, Gosal S, Singh N (2010) In vitro screening of rice (Oryza sativa L) callus for drought tolerance. Int J Agric Biol 5(2): 108-115.

24. Sorkheh K, Shiran B, Kbodambshi M, Rouhi V, Ercisli S (2011) In vitro assay of native Iranian almond species (Prunus L. spp.) for drought tolerance. Plant Cell Tiss Org 10: 395-404. Doi: 10.1007/s11240-010-9879-1.

25. Suprasanna P, Mirajkar S (2015) Induced mutation and crop improvement. In: Bahadur B, Rajam MV, Sahijram L, Krishnamurthy KV (eds.) Plant biology and biotechnology: Vol 1: Plant diversity. Organization, function and improvement. Springer, New Delhi, pp 593-617.

26. Villarreal ML, Herrera CB (2018) Requerimiento hídrico en el sistema de producción vainilla (Vanilla planifolia Jacks. Ex Andrews)- Naranjo (Citrus sinensis L.) en la región del Totonacapan, Veracruz, México. Agroproductividad 11 (3): 29-36.

27. Yang WJ, Rich PJ, Axtell JD, Wood KV, Bonham CC, Ejeta G, Mickelbart MV, Rhodes D (2003) Genotypic variation for glycinebetaine in sorghum. Crop Sci 43 (1): 162-169. https://doi.org/10.2135/cropsci2003.1620.

\section{Tables}




\begin{tabular}{|c|c|c|c|c|}
\hline Treatment & Number of shoots & Shoots length & Number of leaves & Stem diameter \\
\hline 0 Gy & $5.89 \pm 0.92 a b c$ & $11.14 \pm 3.86 a b c d$ & $1.92 \pm 0.67 \mathrm{abcd}$ & $4.33 \pm 0.78 a$ \\
\hline $0.5 \mathrm{~Gy}$ & $8.88 \pm 3.04 a^{*}$ & $19.26 \pm 6.87 a^{*}$ & $2.22 \pm 0.55 a b^{*}$ & $4.88 \pm 0.69 a$ \\
\hline $1 \mathrm{~Gy}$ & $6.43 \pm 0.98 a b^{\star}$ & $6.67 \pm 1.54 \mathrm{de}^{\star}$ & $2.33 \pm 0.68 a b^{\star}$ & $4.11 \pm 0.83 a$ \\
\hline 3 Gy & $5.80 \pm 2.65 a b c$ & $9.59 \pm 2.84 \mathrm{bcde}$ & $2.38 \pm 0.71 a^{*}$ & $4.54 \pm 0.93 a$ \\
\hline 5 Gy & $6.00 \pm 2.0 \mathrm{abc}$ & $9.28 \pm 3.59 \mathrm{bcde}$ & $1.78 \pm 0.59 \mathrm{abcd}$ & $4.88 \pm 0.83 a$ \\
\hline $7 \mathrm{~Gy}$ & $4.88 \pm 0.83 \mathrm{abcd}$ & $13.78 \pm 5.58 \mathrm{abc}$ & $2.29 \pm 0.91 a b$ & $4.5 \pm 0.83 a$ \\
\hline 9 Gy & $1.89 \pm 1.29 \mathrm{~d}^{*}$ & $8.06 \pm 2.94 \mathrm{de}^{\star}$ & $1.44 \pm 0.70 \mathrm{~cd}^{*}$ & $4.39 \pm 0.78 a$ \\
\hline $11 \mathrm{~Gy}$ & $4.67 \pm 1.50 \mathrm{abcd}$ & $8.83 \pm 3.60$ cde & $1.17 \pm 0.49 d^{*}$ & $4.09 \pm 1.12 a$ \\
\hline $13 \mathrm{~Gy}$ & $4.75 \pm 0.71 \mathrm{abcd}$ & $13.94 \pm 5.24 a b c$ & $1.76 \pm 0.83 \mathrm{abcd}$ & $4.65 \pm 1.11 a$ \\
\hline 15 Gy & $2.88 \pm 0.64 \mathrm{~cd}^{*}$ & $16.5 \pm 6.95 a b^{*}$ & $1.59 \pm 0.59 \mathrm{bcd}$ & $4.00 \pm 1.15 a$ \\
\hline $17 \mathrm{~Gy}$ & $3.33 \pm 1.03 \mathrm{abcd}$ & $11.23 \pm 2.68 \mathrm{abcd}$ & $1.71 \pm 0.91 \mathrm{bcd}$ & $4.06 \pm 0.66 a$ \\
\hline 19 Gy & $4.00 \pm 1.41 \mathrm{abcd}$ & $5.87 \pm 1.77 e^{\star}$ & $1.33 \pm 0.49 c^{\star} \star$ & $3.89 \pm 1.08 a$ \\
\hline
\end{tabular}


Table 2 Morphological variation of irradiated seedlings of $V$. planifolia after 70 days in osmotic stress induced by different doses of PEG

\begin{tabular}{|c|c|c|c|c|c|c|c|c|c|c|}
\hline Treatment & $\begin{array}{l}\text { Stem } \\
\text { length }\end{array}$ & Diameter & $\begin{array}{l}\text { Leaf } \\
\text { length }\end{array}$ & $\begin{array}{l}\text { Leaf } \\
\text { width }\end{array}$ & Leaf thickness & $\begin{array}{l}\mathrm{N} \\
\text { of }\end{array}$ & & $\begin{array}{l}\text { Fresh } \\
\text { weight }\end{array}$ & $\begin{array}{l}\text { Root } \\
\text { length }\end{array}$ & $\begin{array}{l}\text { Number } \\
\text { of roots }\end{array}$ \\
\hline \multicolumn{11}{|l|}{ PEG $0 \%$} \\
\hline 0 Gy & $\begin{array}{l}3.33 \pm \\
0.65\end{array}$ & $\begin{array}{l}2.55 \pm \\
0.35 \mathrm{ab}\end{array}$ & $\begin{array}{l}2.18 \pm \\
0.72\end{array}$ & $\begin{array}{l}0.68 \pm \\
0.30\end{array}$ & $\begin{array}{l}0.51 \pm \\
0.09\end{array}$ & $\begin{array}{l}2.90 \pm \\
0.15\end{array}$ & $\begin{array}{l}0.6 \\
0.1\end{array}$ & & $\begin{array}{l}2.85 \pm \\
1.00 b^{*}\end{array}$ & $3.44 \pm 1.24$ \\
\hline 3 Gy & $\begin{array}{l}3.87 \pm \\
0.82\end{array}$ & $\begin{array}{l}3.03 \pm \\
0.22 \mathbf{a}^{*}\end{array}$ & $\begin{array}{l}2.63 \pm \\
0.78\end{array}$ & $\begin{array}{l}0.95 \pm \\
0.36\end{array}$ & $\begin{array}{l}0.61 \pm \\
0.18\end{array}$ & $\begin{array}{l}2.90 \pm \\
0.88\end{array}$ & $\begin{array}{l}1.1 \\
0.4\end{array}$ & & $\begin{array}{l}4.92 \pm \\
2.38 \mathrm{ab}\end{array}$ & $4.80 \pm 1.14$ \\
\hline 7 Gy & $\begin{array}{l}3.15 \pm \\
0.57\end{array}$ & $\begin{array}{l}2.70 \pm \\
0.59 \mathrm{ab}\end{array}$ & $\begin{array}{l}3.26 \pm \\
0.69\end{array}$ & $\begin{array}{l}1.13 \pm \\
0.33\end{array}$ & $\begin{array}{l}0.61 \pm \\
0.22\end{array}$ & $\begin{array}{l}3.30 \pm \\
1.34\end{array}$ & $\begin{array}{l}0.8 \\
0.2\end{array}$ & & $\begin{array}{l}4.99 \pm \\
1.33 \mathrm{ab}\end{array}$ & $3.80 \pm 1.14$ \\
\hline 13 Gy & $\begin{array}{l}3.51 \pm \\
0.77\end{array}$ & $\begin{array}{l}2.53 \pm \\
0.33 b^{*}\end{array}$ & $\begin{array}{l}3.08 \pm \\
0.85\end{array}$ & $\begin{array}{l}1.10 \pm \\
0.36\end{array}$ & $\begin{array}{l}0.44 \pm \\
0.10\end{array}$ & $\begin{array}{l}4.30 \pm \\
1.57\end{array}$ & $\begin{array}{l}1.2 \\
0.4\end{array}$ & * & $\begin{array}{l}6.33 \pm \\
2.26 a^{*}\end{array}$ & $4.30 \pm 1.64$ \\
\hline
\end{tabular}

PEG $10 \%$

\begin{tabular}{|c|c|c|c|c|c|c|c|c|c|}
\hline 0 Gy & $\begin{array}{l}1.95 \pm \\
0.31\end{array}$ & $\begin{array}{l}2.40 \pm \\
0.33 \mathrm{ab}\end{array}$ & $\begin{array}{l}2.79 \pm \\
0.68\end{array}$ & $\begin{array}{l}0.87 \pm \\
0.20\end{array}$ & $\begin{array}{l}0.38 \pm \\
0.12\end{array}$ & $\begin{array}{l}1.70 \pm \\
0.48 b^{*}\end{array}$ & $\begin{array}{l}0.44 \pm \\
0.12 \mathrm{ab}\end{array}$ & $\begin{array}{l}2.20 \pm \\
0.80 \mathrm{ab}\end{array}$ & $2.60 \pm 0.52$ \\
\hline 3 Gy & $\begin{array}{l}2.14 \pm \\
0.34\end{array}$ & $\begin{array}{l}2.66 \pm \\
0.13 a^{*}\end{array}$ & $\begin{array}{l}2.96 \pm \\
0.78\end{array}$ & $\begin{array}{l}1.09 \pm \\
0.23\end{array}$ & $\begin{array}{l}0.41 \pm \\
0.23\end{array}$ & $\begin{array}{l}1.60 \pm \\
0.70 b^{\star}\end{array}$ & $\begin{array}{l}0.64 \pm 0.29 \\
\mathbf{a}^{*}\end{array}$ & $\begin{array}{l}2.42 \pm \\
0.96 \mathrm{ab}\end{array}$ & $2.40 \pm 1.17$ \\
\hline $7 \mathrm{~Gy}$ & $\begin{array}{l}2.04 \pm \\
0.23\end{array}$ & $\begin{array}{l}2.15 \pm \\
0.42 b^{*}\end{array}$ & $\begin{array}{l}2.85 \pm \\
0.65\end{array}$ & $\begin{array}{l}0.92 \pm \\
0.29\end{array}$ & $\begin{array}{l}0.45 \pm \\
0.19\end{array}$ & $\begin{array}{l}2.2 \pm \\
0.63 \mathrm{ab}\end{array}$ & $\begin{array}{l}0.36 \pm 0.15 \\
b^{*}\end{array}$ & $\begin{array}{l}1.72 \pm \\
0.92 \\
b^{*}\end{array}$ & $2.60 \pm 1.35$ \\
\hline $13 \mathrm{~Gy}$ & $\begin{array}{l}2.27 \pm \\
0.35\end{array}$ & $\begin{array}{l}2.16 \pm \\
0.27 b^{\star}\end{array}$ & $\begin{array}{l}2.83 \pm \\
1.16\end{array}$ & $\begin{array}{l}0.98 \pm \\
0.17\end{array}$ & $\begin{array}{l}0.47 \pm \\
0.16\end{array}$ & $\begin{array}{l}2.89 \pm \\
0.78 \mathbf{a}^{*}\end{array}$ & $\begin{array}{l}0.54 \pm \\
0.15 \mathrm{ab}\end{array}$ & $\begin{array}{l}3.43 \pm \\
1.53 \\
a^{*}\end{array}$ & $1.90 \pm 1.29$ \\
\hline
\end{tabular}

PEG $15 \%$

\begin{tabular}{|c|c|c|c|c|c|c|c|c|c|}
\hline 0 Gy & $\begin{array}{l}1.92 \pm \\
0.12\end{array}$ & $\begin{array}{l}1.99 \pm \\
0.48 b *\end{array}$ & $\begin{array}{l}2.11 \pm \\
0.61 b^{*}\end{array}$ & $\begin{array}{l}0.73 \pm \\
0.19 b^{*}\end{array}$ & $\begin{array}{l}0.35 \pm \\
0.12 b *\end{array}$ & $\begin{array}{l}1.60 \pm \\
0.52 c^{*}\end{array}$ & $\begin{array}{l}0.24 \pm \\
0.08 b^{*}\end{array}$ & $\begin{array}{l}0.70 \pm \\
0.32 b^{*}\end{array}$ & $0.70 \pm 0.67$ \\
\hline 3 Gy & $\begin{array}{l}2.11 \pm \\
0.33\end{array}$ & $\begin{array}{l}2.58 \pm \\
0.25 a^{*}\end{array}$ & $\begin{array}{l}3.13 \pm \\
0.49 \\
a^{*}\end{array}$ & $\begin{array}{l}1.09 \pm \\
0.23 \mathbf{a}^{*}\end{array}$ & $\begin{array}{l}0.45 \pm \\
0.11 \mathrm{ab}\end{array}$ & $\begin{array}{l}1.90 \pm \\
0.74 \mathrm{bc}^{*}\end{array}$ & $0.53 \pm 0.2 a *$ & $\begin{array}{l}1.28 \pm \\
0.43 \mathrm{a}^{*}\end{array}$ & $1.70 \pm 0.67$ \\
\hline 7 Gy & $\begin{array}{l}1.97 \pm \\
0.24\end{array}$ & $\begin{array}{l}2.40 \pm \\
0.48 a^{2}\end{array}$ & $\begin{array}{l}3.20 \pm \\
1.06 \\
a^{*}\end{array}$ & $\begin{array}{l}1.00 \pm \\
0.28 \mathrm{ab}\end{array}$ & $\begin{array}{l}0.38 \pm \\
0.20 \mathrm{ab}\end{array}$ & $\begin{array}{l}2.70 \pm \\
0.82 a b *\end{array}$ & $\begin{array}{l}0.41 \pm \\
0.13 \mathrm{ab}\end{array}$ & $\begin{array}{l}0.98 \pm \\
0.20 \\
a b\end{array}$ & $1.5 \pm 0.85$ \\
\hline $13 \mathrm{~Gy}$ & $\begin{array}{l}1.91 \pm \\
0.19\end{array}$ & $\begin{array}{l}2.21 \pm \\
0.36 \mathrm{ab}^{*}\end{array}$ & $\begin{array}{l}3.21 \pm \\
0.70 \mathbf{a}^{*}\end{array}$ & $\begin{array}{l}1.11 \pm \\
0.31 a^{*}\end{array}$ & $\begin{array}{l}0.59 \pm \\
0.24 a^{*}\end{array}$ & $\begin{array}{l}3.10 \pm \\
0.99 a^{*}\end{array}$ & $\begin{array}{l}0.40 \pm \\
0.08 \mathbf{a b}\end{array}$ & $\begin{array}{l}1.15 \pm \\
0.21 a^{*}\end{array}$ & $0.60 \pm 0.52$ \\
\hline
\end{tabular}

* in letters indicate the significant differences $(p<.05)$ between the irradiation doses per PEG level

\section{Figures}




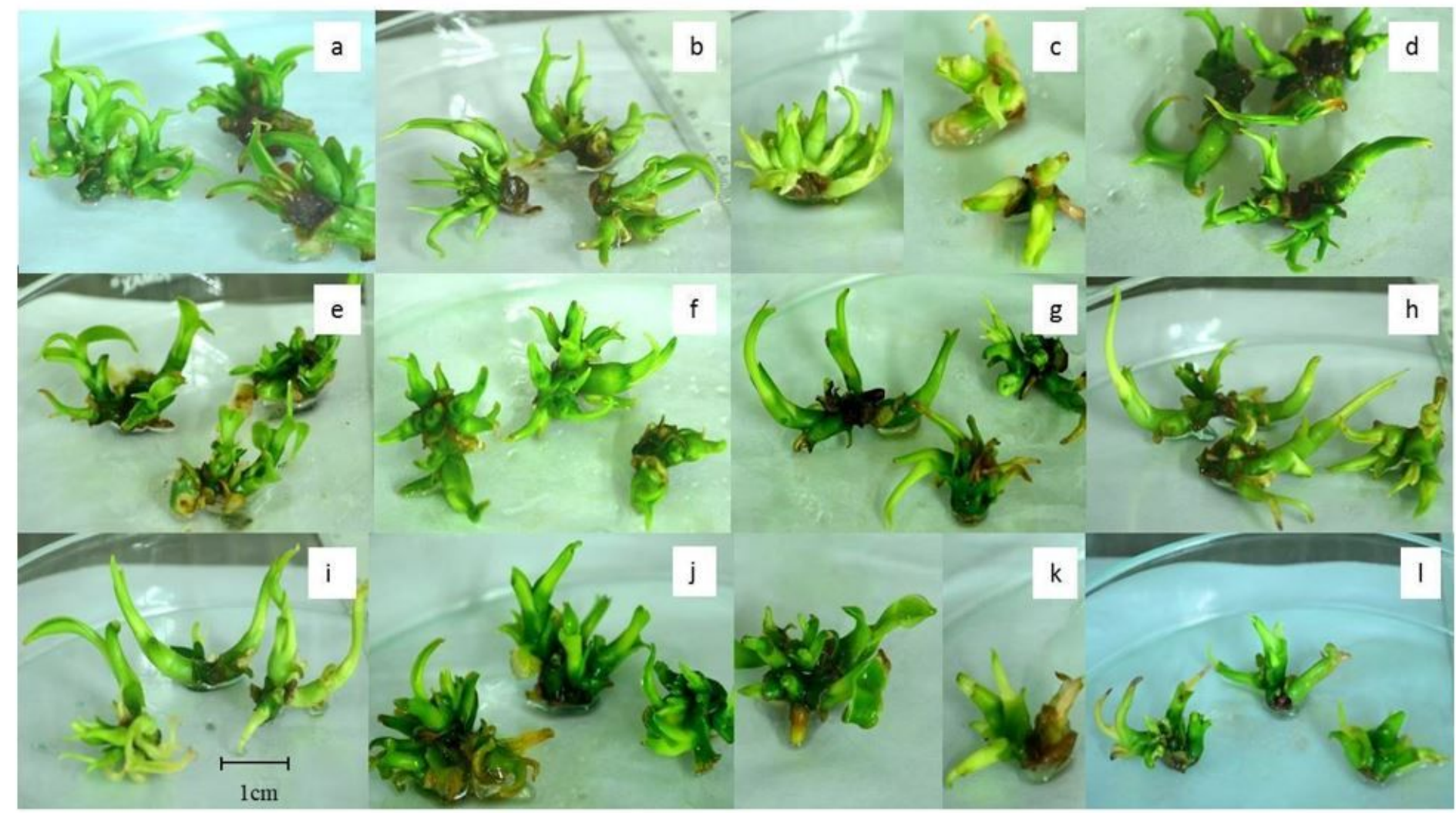

\section{Figure 1}

Effect to various doses of gamma radiation on the appearance of shoots two months after irradiation. a) 0Gy, b) 0.5Gy, c) $1 \mathrm{~Gy}$, d) 3Gy, e) 5Gy, f)7Gy, g) 9Gy, h)11 Gy, i) 13 Gy, j) 15 Gy, k) 17 Gy, I) 19 Gy 

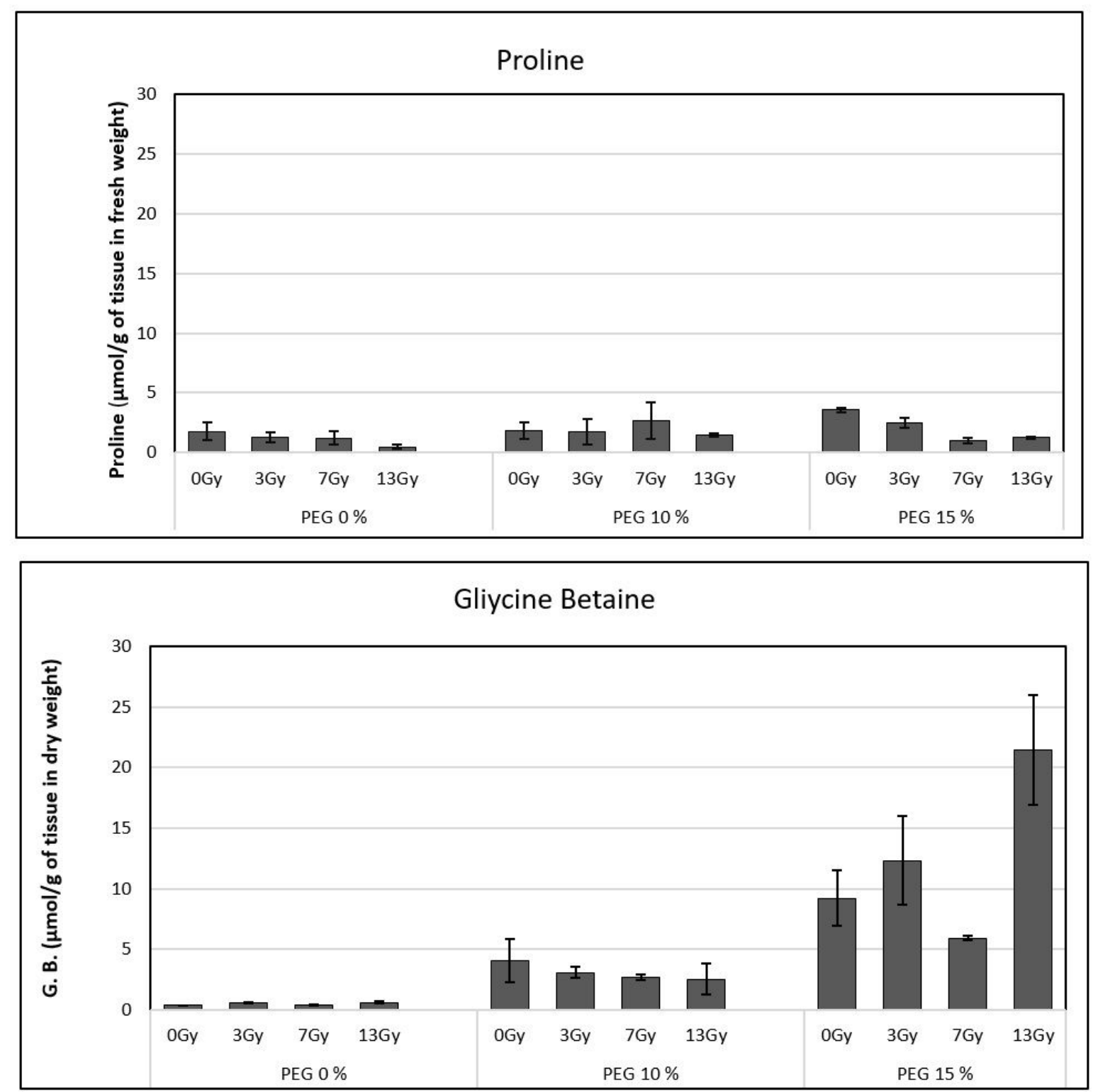

Figure 2

Comparison of Proline and Glycine Betaine concentration in irradiated seedlings of Vanilla planifolia subjected to PEG 